\title{
Patient Satisfaction with Primary Health Care Services in a Selected District Municipality of the Eastern Cape of South Africa
}

\author{
N. Phaswana-Mafuya ${ }^{1,2}$, A. S. Davids ${ }^{1}$, I. Senekal ${ }^{3}$ and S. Munyaka ${ }^{3}$ \\ ${ }^{1}$ Human Sciences Research Council, Port Elizabeth, \\ ${ }^{2}$ Office of the Deputy Vice Chancellor: Research and Engagement, Nelson Mandela \\ Metropolitan University, Port Elizabeth, \\ ${ }^{3}$ University of Fort Hare, \\ South Africa
}

\section{Introduction}

Traditionally, decisions about health services were made on the basis of health-provider and health authorities' views on what is in the best interest of the patient. This was based on a view that members of the general public lack the technical knowledge to make fully informed decisions themselves. Currently, the use of patient satisfaction surveys (PSS) in developing countries is advancing. Professionals have recognized that a systematic and consumer oriented perspective toward patient viewpoints about the level of care can result in feedback useful for promoting higher quality standards of patient care (Dağdeviren \& Akturk 2004; Newman et al. 1998; Peltzer 2009).

Patient satisfaction surveys are seen as a means of determining patients' views on primary health care (PHC) (Ajayi, Olumide \& Oyediran 2005; Andaleeb 2001; Campbell, Ramsay \& Green 2001). These surveys are increasingly being promoted as a means of understanding health care service quality and the demand for these services in developing countries (Glick 2009) for various reasons. First, they highlight those aspects of care that need improvement in a health care setting (Ajayi, Olumide \& Oyediran 2005; Muhondwa et al. 2008; Newman et al. 1998). Second, they are simple, quick and inexpensive to administer. Third, they are critical for developing measures to increase the utilization of PHC services. Fourth, they can help to educate medical staff about their achievements as well as their failures, assisting them to be more responsive to their patients' needs. Fifth, they allow managerial judgment to be exercised from a position of knowledge rather than guesswork in the important task of managing public expectations and resources (Glick 2009).

The South African government also endorses the centrality of consumers in service delivery. The White Paper on Transforming Public Services of 1997 (Department of Public Service and Administration 1997) and the Department of Health's policy on quality in health care (Department of Health 2007) state that public services need to respond to customers' needs, wants and expectations. Feedback from consumers is required in terms of experiences of health services - quality of care received. Feedback from customers will not only improve 
knowledge of decision makers, but will also facilitate more improved prioritization, improved strategic resource allocation and improved value for money. It will also serve as a platform for providing better services to citizens.

Against this background, a patient satisfaction survey with PHC services was conducted in a selected district of the Eastern Cape.

\section{Methods}

\subsection{Design and setting}

A cross-sectional descriptive design was employed to collect data among patients visiting 12 clinics in a selected health district of the Eastern Cape of South Africa in 2009. The majority of the South Africans are dependent on the public health sector, with only $15 \%$ of the citizenry belonging to a private medical aid scheme (McIntyre, 2010). In the Eastern Cape, private medical aid covers only $10.9 \%$ of the province's population and less than $7 \%$ of South Africa's private and independent hospitals, are located in the Eastern Cape (Hospital Association of South Africa, 2011). The current study focused on public health services (the main provider of health care) in a selected district in the Eastern Cape. We did not ask about private health care utilization.

The public health system of the Eastern Cape consists of 817 clinics, 81 hospitals and 18 community health care centres. The core norms, set by the National Department of Health in South Africa, for primary health care services are indicated in Table 1. Statistics South Africa estimated that the mid-year population for Eastern Cape in 2010 was 6743800 , about $13,5 \%$ of the estimated total population of South Africa. Persons under the age of 15 years constitute $32.8 \%$ of the total population and the economically active population (1564 years) is $61.2 \%$ of total population of the Eastern Cape. For the period 2006 to 2011 it is estimated that approximately 211600 people will migrate from the Eastern Cape to other provinces of the country (Statistics South Africa, 2010). The burden of disease study for the year 2000, estimated that South Africans suffer from poverty-related diseases and conditions, emerging chronic diseases, injuries and HIV/AIDS, and differences in morbidity and mortality between socioeconomic groups (Bradshaw et al., 2003). The Eastern Cape had an estimated 23.6\% unemployment rate at the end of the second quarter of 2009. This drives levels of poverty in the province, as those deemed to be living in poverty was 3564504 , nearly $53 \%$ of the 2010 midyear population. The corresponding figure for South Africa is $38 \%$, making the province one of the poorest in the country (ECSECC, 2011).

\subsection{Sample and procedure}

A purposive sample of 836 out of 939 patients (89\% response rate), visiting 12 primary care facilities in a selected district of the Eastern Cape of South Africa were interviewed while exiting the clinic. Patients aged 18 years or above were considered eligible, provided that they were able to understand and respond to the interview questions. Patients were interviewed face to face by trained interviewers in their preferred language in five consecutive days per clinic. Two fieldworkers and one fieldwork coordinator (with at least a high school certificate) were trained per clinic. Two of the four local fieldworkers conducted the interviews in the respective clinics, while the other two served as a reserve. A clinic nurse supervised and coordinated the fieldwork process in the clinic where s/he was based 
in. Ethics approval for the study protocol was obtained from the University of Fort Hare's Research Ethics Committee and permission to conduct the study was received from the Eastern Cape Department of Health.

\begin{tabular}{|c|c|}
\hline Core Norms & Core Services \\
\hline $\begin{array}{l}\text { - The clinic renders comprehensive integrated PHC } \\
\text { services using a one-stop approach for at } \\
\text { least } 8 \text { hours a day, five days a week. } \\
\text { - Access, as measured by the proportion of people } \\
\text { living within 5km of a clinic, is improved. } \\
\text { least once a month to support personnel, } \\
\text { monitor the quality of service and identify } \\
\text { needs and priorities. } \\
\text { - The clinic has at least one member of staff who has } \\
\text { completed a recognised PHC course. } \\
\text { - Doctors and other specialised professionals are } \\
\text { accessible for consultation, support and } \\
\text { referral and provide periodic visits. } \\
\text { - Clinic managers receive training in facilitation skills } \\
\text { and primary health care management. } \\
\text { - There is an annual evaluation of the provision of the } \\
\text { PHC services to reduce the gap between } \\
\text { needs and service provision using a situation } \\
\text { analysis of the community's health needs } \\
\text { and the regular health information data } \\
\text { collected at the clinic. } \\
\text { - There is annual plan based on this evaluation. } \\
\text { and quality assurance and at least one } \\
\text { annual service audit. } \\
\text { - Community perception of services is tested at least } \\
\text { - Thear through patient interviews or } \\
\text { - }\end{array}$ & $\begin{array}{l}\text { - Women's Reproductive Health } \\
\text { - Illness } \\
\text { - Diseases prevented by Immunisation } \\
\text { - Adolescent and Youth Health } \\
\text { - Management of Communicable Disease } \\
\text { - Control of Cholera, diarrhoeal disease and } \\
\quad \text { dysentery } \\
\text { - Helminths } \\
\text { - Sexual Transmitted Diseases (STD)and } \\
\text { - MIV/AIDS } \\
\text { - Rabies } \\
\text { - Tuberculosis } \\
\text { - Leprosy } \\
\text { - Prevention of Hearing Impairment due to } \\
\text { Otitis Media } \\
\text { - Rheumatic Fever and Haemolytic } \\
\text { - Streptococcal Infection } \\
\text { - Trauma and Emergency } \\
\text { - Oral and Mental Health } \\
\text { - Treatment and support of victims of Sexual } \\
\text { Offenses, Domestic Violence and } \\
\text { Gender Violence }\end{array}$ \\
\hline
\end{tabular}

Source: Department of Health, South Africa

Table 1. The core norms and services for primary health care PHC set by the NDOH.

\subsection{Data collection method}

A patient satisfaction questionnaire adapted from the one developed by the Health Systems Trust in 2004 was used. Only slight changes were made to the questionnaire in collaboration with the Eastern Cape Department of Health to allow for cross-comparisons with earlier patient surveys that have been undertaken within the Eastern Cape Province using the same 
questionnaire. Further, some questions were asked on demographics, health status, reason for health visit, and health care utilization. The questionnaire was translated from English into Afrikaans and Xhosa. The Xhosa and Afrikaans versions were developed using backtranslation methods (Brislin 1970). The procedure entailed having two native-speakers of the target languages independently do a back-translation. Discrepancies were arbitrated by a third consultant, and solutions were reached by consensus. The translated questionnaire underwent pilot-testing.

\subsection{Measures}

The questionnaire included demographics and eight domains, each having several items on a 5-point likert scale: Strongly Agree=5; Agree=4; Unsure=3; Disagree=2; and Strongly Disagree $=1$

\subsection{Data analysis}

Data was captured on SPSS version 17.0 and analysed. Frequency distributions of domain items were made and positive responses (Agree and Strongly agree) were grouped and are presented. Cross tabulations of domain items by gender were made. Chi square tests were performed to determine the relationship between each domain item and gender.

\subsection{Limitations}

Response biases introduced through the methodology of using exit interviews might act as filters and influence patient satisfaction ratings. For example, exit interviews automatically select out those who do not have access to public health facilities, but would otherwise have used services. In addition, using exit interviews in health facilities identified by the subdistrict officials, means that respondents were purposively selected. Non-randomisation in the selection of respondents means that results are more difficult to generalise to a feeder population around a health facility. The study compensated for this limitation by collecting data from each facility over a week during a period of normal use and through achieving a high number of respondents. A further limitation is that the existing PSS methodology does not enable the relationship between aggregate satisfaction scores and changes in health status of populations to be explored.

\section{Results}

\subsection{Sample characteristics}

The majority of the respondents were African (50.9\%), female (72.9) and unemployed (56.4\%) with a mean age of 39.4 years. Only $5.5 \%$ of the respondents indicated that they had enough money to meet their basic needs for most of the time. Almost $85 \%$ had some form of formal education.

\subsection{Utilization of health services}

Most respondents visited clinics more frequently (i.e. about 7 times within 12 months) compared to private doctors (i.e. about 1.58 times), hospitals (i.e. about 1.14 times) and traditional healers were list visited ( 0.23 times). The main reason for visiting the health facility was to get treatment $(41.8 \%)$, followed by suffering from non-communicable diseases (NCDs) $(11.5 \%)$ and family planning (10.1\%). 


\begin{tabular}{|l|l|}
\hline Mean Age: M (SD) & 39 years (14.91) \\
\hline Gender & $\mathbf{N ~ ( \% )}$ \\
\hline Male & $230(29.9)$ \\
\hline Female & $674(72.9)$ \\
\hline Race & $\mathbf{N}(\mathbf{\%})$ \\
\hline African & $469(50.9)$ \\
\hline White & $26(2.8)$ \\
\hline Indian & $10(1.1)$ \\
\hline Coloured & $375(40.7)$ \\
\hline Other & $39(4.2)$ \\
\hline Occupation & $\mathbf{N ~ ( \% )}$ \\
\hline Employed & $335(37.1)$ \\
\hline Not Employed & $509(56.4)$ \\
\hline Other & $59(6.4)$ \\
\hline Highest Level of Education & $\mathbf{N ~ ( \% )}$ \\
\hline None & $139(15.4)$ \\
\hline Finished primary & $325(36.0)$ \\
\hline Finished Grade 10 & $266(29.4)$ \\
\hline Finished Grade 12 & $108(11.9)$ \\
\hline Degree/Diploma & $12(1.3)$ \\
\hline Other & $54(6.0)$ \\
\hline Enough Money to meet own needs & $\mathbf{N ~ ( \% )}$ \\
\hline None & $354(39.3)$ \\
\hline A little & $318(35.3)$ \\
\hline Moderately & $112(12.4)$ \\
\hline Mostly & $40(4.4)$ \\
\hline Completely & $10(1.1)$ \\
\hline Other & $67(7.4)$ \\
\hline &
\end{tabular}

Table 2. Demographic Characteristics.

\begin{tabular}{|l|l|}
\hline Items & M (SD) \\
\hline Mean no. of clinic visits in 12 months & $8.48(6.798)$ \\
\hline Mean no. of hospital visits in 12 months & $1.14(1.905)$ \\
\hline $\begin{array}{l}\text { Mean no. of private doctor visits in } 12 \\
\text { months }\end{array}$ & $1.58(2.520)$ \\
\hline $\begin{array}{l}\text { Mean no. of traditional healer visits in } 12 \\
\text { months }\end{array}$ & $0.23(1.121)$ \\
\hline Main reason for visiting health facility & $\mathrm{N} \mathrm{( \% )}$ \\
\hline Non-communicable diseases & $108(11.5)$ \\
\hline Communicable diseases & $\mathbf{4 0 ( 4 . 3 )}$ \\
\hline Treatment & $\mathbf{3 9 1}(\mathbf{4 1 . 8 )}$ \\
\hline Treatment (for baby or child) & $\mathbf{5 7 ( 6 . 1 )}$ \\
\hline Bodily aches & $\mathbf{4 7 ( 5 . 0 )}$ \\
\hline Family Planning & $\mathbf{9 5 ( 1 0 . 1 )}$ \\
\hline Other/Unidentified & $\mathbf{1 9 8 ( 2 1 . 2 )}$ \\
\hline
\end{tabular}

Table 3. Health Care Utilization. 


\subsection{Symptom reporting}

More than two-thirds reported that coughing, headache, fever, and body/limb aches were the symptoms suffered in descending order.

\begin{tabular}{|l|l|}
\hline Symptoms & N (\%) \\
\hline Coughing & $183(87.1)$ \\
\hline Body/limb aches & $110(80.3)$ \\
\hline Fever & $153(85.0)$ \\
\hline Rash & $46(63.0)$ \\
\hline Headache & $178(86.8)$ \\
\hline Diarrhoea & $23(46.0)$ \\
\hline
\end{tabular}

Table 4. Symptom Reporting.

\subsection{Prior diagnosis}

More than $60 \%$ of the respondents indicated that they had prior diagnosis of other STIs (95\%), other illnesses (88.9\%), TB (78.4\%), Diabetes (72.2\%), High Blood Pressure $(69.3 \%)$ and HIV $(65.2 \%)$.

\begin{tabular}{|l|l|}
\hline Prior Diagnosis & $\mathbf{N}(\mathbf{\%})$ \\
\hline TB & $105(78.4)$ \\
\hline HIV & $56(65.1)$ \\
\hline Diabetes & $78(72.2)$ \\
\hline Other STI & $891(94.9)$ \\
\hline High Blood Pressure & $651(69.3)$ \\
\hline Pregnancy & $38(55.1)$ \\
\hline Other illness & $835(88.9)$ \\
\hline
\end{tabular}

Table 5: Prior diagnosis.

\section{Descriptions of patients evaluations: percentage of patients who used the most positive answering category by sex ( $N=836$, percentages)}

\subsection{Access to PHC services}

A larger portion of women respondents positively agreed with the items from the access domain, than did men. More than three quarters of women agreed that it was possible to get an appointment that suited them and about the same number indicated that no payment was required for treatment at that clinic. About three quarters of women also agreed that it was possible to get through to the clinic by telephone and that the clinic was disabilityfriendly. The same number of women also agreed that they were treated by nurses who spoke a language they could understand and that the clinic's opening hours were convenient. Nearly $75 \%$ of women further agreed that they are always treated and not asked to return on another day and that is was possible to speak to the nurse on the phone. More than seven in ten women did not think that nurses did not visit their places of residence often enough. In terms of time and financial costs, about seven in ten women respondents agreed that the journey there took longer than one hour and that it costs more than R10-00 (US\$1.46) to get to the clinic. 


\begin{tabular}{|l|c|c|c|c|}
\hline Item & $\begin{array}{c}\text { Men: N } \\
(\mathbf{\%})\end{array}$ & $\begin{array}{c}\text { Women: } \mathbf{N} \\
(\%)\end{array}$ & $\begin{array}{c}\text { Total: } \mathbf{~} \\
(\%)\end{array}$ & $\mathbf{P}$ \\
\hline $\begin{array}{l}\text { It takes longer than an hour to go to the } \\
\text { clinic }\end{array}$ & $70(27.5)$ & $184(72.2)$ & $255(27.2)$ & 0.067 \\
\hline $\begin{array}{l}\text { It cost more than R10.00 to get to the } \\
\text { clinic }\end{array}$ & $50(29.2)$ & $120(70.2)$ & $171(18.2)$ & 0.218 \\
\hline The clinic has convenient opening hours & $161(25.8)$ & $461(74.0)$ & $623(66.3)$ & 0.982 \\
\hline $\begin{array}{l}\text { I don't think healthworkers /nurses come } \\
\text { often enough to the place where I stay }\end{array}$ & $76(27.4)$ & $201(72.6)$ & $277(29.5)$ & 0.689 \\
\hline I paid money to be treated in this clinic & $28(24.6)$ & $86(75.4)$ & $144(12.1)$ & 0.088 \\
\hline $\begin{array}{l}\text { The nurse who treated me spoke in a } \\
\text { language I understood }\end{array}$ & $191(25.5)$ & $556(74.3)$ & $748(79.7)$ & 0.07 \\
\hline $\begin{array}{l}\text { When I come to this clinic I'm always } \\
\text { treated \& never told to return on another } \\
\text { day }\end{array}$ & $155(25.8)$ & $445(74.0)$ & $601(64.0)$ & 0.478 \\
\hline $\begin{array}{l}\text { The clinic is user friendly to disabled } \\
\text { persons }\end{array}$ & $153(25.4)$ & $449(74.6)$ & $602(64.1)$ & 0.265 \\
\hline Getting an appointment to suit you & $114(23.7)$ & $367(76.3)$ & $481(51.2)$ & 0.429 \\
\hline $\begin{array}{l}\text { Getting through to the clinic on the } \\
\text { phone }\end{array}$ & $101(25.0)$ & $303(75.0)$ & $404(43.1)$ & 0.834 \\
\hline $\begin{array}{l}\text { Being able to speak to the nurse } \\
\text { practitioner on the telephone }\end{array}$ & $93(26.6)$ & $256(73.4)$ & $349(37.2)$ & 0.588 \\
\hline
\end{tabular}

Table 6. Perceived Access to PHC Services.

\subsection{Perceived empathy}

Women, when compared to men, were also more positive in their responses to items of the empathy domain. More than three quarters of women respondents agreed that their privacy was respected by all the staff involved in their treatment, that the nurse/doctor who treated them was polite and that they could answer all questions about their illness. The same number felt that this made it easy to tell the doctor/nurse about their problems. Just under three quarters of women respondents agreed that the nurse/doctor who treated them introduced themselves, that they gave their permission to be examined and treated and made them feel they had time during consultations.

\subsection{General satisfaction}

Larger proportions of women when compared to men had positive responses on items of this domain. Almost eight in ten women respondents positively agreed that patients do not usually appreciate all that the clinic staff does for them. More than three in four also agreed that staff do inform clients of changes in service, as well as any delays in services, on occasion. The same proportion of women agreed that their treatment is always better when an injection is administered and that they are pleased with the way they were treated at the clinic. Nearly three quarters agreed that they always get treatment when attending the clinic where they were interviewed and that they would attend the same facility again on another occasion. The same number will also recommend the clinic to friends and family when should they be sick. Despite these figures, just more than six in ten women agreed that the staff were helpful. 


\begin{tabular}{|l|c|c|c|c|}
\hline Item & $\begin{array}{c}\text { Men: N } \\
(\mathbf{\%})\end{array}$ & $\begin{array}{c}\text { Women: N } \\
(\%)\end{array}$ & $\begin{array}{c}\text { Total: N } \\
(\mathbf{\%})\end{array}$ & $\mathbf{P}$ \\
\hline $\begin{array}{l}\text { The nurse/Doctor who treated me } \\
\text { introduced him/herself }\end{array}$ & $121(25.9)$ & $348(73.9)$ & $468(49.8)$ & 0.49 \\
\hline $\begin{array}{l}\text { The nurse/Doctor who treated me } \\
\text { answered all questions about my illness }\end{array}$ & $162(24.8)$ & $490(75.0)$ & $653(69.5)$ & 0.474 \\
\hline $\begin{array}{l}\text { I gave permission to be examined and } \\
\text { treated }\end{array}$ & $185(25.4)$ & $543(74.5)$ & $729(77.6)$ & 0.908 \\
\hline My privacy was respected by all the staff & $172(24.2)$ & $538(75.7)$ & $711(75.7)$ & 0.022 \\
\hline $\begin{array}{l}\text { The nurse/ doctor who treated me was } \\
\text { polite }\end{array}$ & $162(24.3)$ & $503(75.5)$ & $666(70.9)$ & 0.251 \\
\hline $\begin{array}{l}\text { The nurse in this clinic are very } \\
\text { interested in their clients }\end{array}$ & $165(25.2)$ & $490(74.7)$ & $656(69.9)$ & 0.883 \\
\hline $\begin{array}{l}\text { Making you feel you had time during } \\
\text { consultations }\end{array}$ & $168(26.4)$ & $469(73.6)$ & $638(67.9)$ & 0.481 \\
\hline Interest in your personal situation & $163(26.1)$ & $462(74.0)$ & $626(66.6)$ & 0.425 \\
\hline $\begin{array}{l}\text { Making it easy for you to tell him or her } \\
\text { about your problems }\end{array}$ & $164(24.8)$ & $497(75.2)$ & $662(70.5)$ & 0.721 \\
\hline
\end{tabular}

Table 7. Empathy.

\begin{tabular}{|l|l|l|l|l|}
\hline Item & $\begin{array}{l}\text { Men: N } \\
(\%)\end{array}$ & $\begin{array}{l}\text { Women: } \\
\mathbf{N}(\%)\end{array}$ & $\begin{array}{l}\text { Total: N } \\
(\mathbf{\%})\end{array}$ & $\mathbf{P}$ \\
\hline Next time I am ill I will come back here & $184(25.0)$ & $551(74.9)$ & $736(78.4)$ & 0.034 \\
\hline $\begin{array}{l}\text { I was pleased with the way I was treated } \\
\text { at this clinic }\end{array}$ & $172(24.0)$ & $544(75.9)$ & $717(76.4)$ & 0.034 \\
\hline $\begin{array}{l}\text { If my friends / family are sick I will tell } \\
\text { them to come to this facility }\end{array}$ & $172(25.0)$ & $514(74.8)$ & $687(73.2)$ & 0.426 \\
\hline $\begin{array}{l}\text { My treatment is always better if I have an } \\
\text { injection }\end{array}$ & $117(23.6)$ & $379(76.4)$ & $496(52.8)$ & 0.147 \\
\hline $\begin{array}{l}\text { Patients don't usually appreciate all that } \\
\text { staff in this clinic do for them }\end{array}$ & $97(21.6)$ & $353(78.4)$ & $450(47.9)$ & 0.008 \\
\hline I always get treatment when I come here & $172(24.6)$ & $526(75.3)$ & $699(74.4)$ & 0.397 \\
\hline $\begin{array}{l}\text { Staff informs clients of delays in service } \\
\text { from time to time }\end{array}$ & $136(23.7)$ & $438(76.3)$ & $574(61.1)$ & 0.042 \\
\hline $\begin{array}{l}\text { Staff informs clients of changes in service } \\
\text { from time to time }\end{array}$ & $128(23.3)$ & $421(76.7)$ & $549(58.5)$ & 0.019 \\
\hline The helpfulness of staff & $277(37.3)$ & $465(62.7)$ & $624(66.4)$ & 0.715 \\
\hline
\end{tabular}

Table 8. General Satisfaction.

\subsection{Referral}

The items in this domain also received a majority of positive responses from women respondents. For example, more than three quarters of women agreed that if they cannot be helped at the clinic they will be referred to the nearest hospital or doctor. They same number was also sure that nurses in this facility will call an ambulance if a client is very sick and that 
nurses in that facility ask patients to return to see how they are doing. The role of traditional healers is still an important aspect of health care, as more than three quarters of women responded that they usually visit a traditional healer before coming to the clinic.

\begin{tabular}{|l|c|c|c|c|}
\hline Item & $\begin{array}{c}\text { Men: N } \\
(\mathbf{\%})\end{array}$ & $\begin{array}{c}\text { Women: } \\
\mathbf{N}(\mathbf{\%})\end{array}$ & $\begin{array}{c}\text { Total: N } \\
(\mathbf{\%})\end{array}$ & P \\
\hline $\begin{array}{l}\text { If I can't be helped here I will be referred } \\
\text { to the nearest hospital/Doctor }\end{array}$ & $163(24.4)$ & $503(75.4)$ & $667(71.0)$ & 0.216 \\
\hline $\begin{array}{l}\text { Nurses in this facility call an ambulance if } \\
\text { a client is very sick }\end{array}$ & $167(24.4)$ & $517(75.5)$ & $685(72.9)$ & 0.358 \\
\hline $\begin{array}{l}\text { Nurses in this facility ask patients to } \\
\text { return to see how they are doing }\end{array}$ & $152(24.2)$ & $475(75.6)$ & $628(66.9)$ & 0.321 \\
\hline $\begin{array}{l}\text { When I'm sick I usually visit a traditional } \\
\text { healer before I come to clinic }\end{array}$ & $42(23.3)$ & $137(76.1)$ & $180(19.2)$ & 0.395 \\
\hline
\end{tabular}

Table 9. Referral.

\subsection{Service standards}

Items in the service standards domain elicited more positive responses from women than from men. More than three in four women responded that they knew either the chairperson or a member of the clinic committee of that clinic that the health worker that assisted them had a name tag on her/him, that they knew where and to whom to raise complaints, and know of the availability of a suggestion box at the clinic. The same number also agreed that the registration procedures in the clinic were satisfactory, waiting time before examination was reasonable and that there were are fast queues in this clinic for certain services. Just fewer than three in four women agreed that when they had reason to complain, they received feedback and that such action improved service delivery.

\begin{tabular}{|l|l|l|l|l|}
\hline Item & $\begin{array}{c}\text { Men: N } \\
(\mathbf{\%})\end{array}$ & $\begin{array}{c}\text { Women: } \\
\mathbf{N}(\mathbf{\%})\end{array}$ & $\begin{array}{c}\text { Total: } \mathbf{~} \\
\mathbf{( \% )}\end{array}$ & $\mathbf{P}$ \\
\hline $\begin{array}{l}\text { The registration procedures in this clinic } \\
\text { are satisfactory }\end{array}$ & $148(24.7)$ & $451(75.2)$ & $600(63.9)$ & 0.005 \\
\hline $\begin{array}{l}\text { In this clinic the time I had to wait before I } \\
\text { was examined was reasonable }\end{array}$ & $127(25.5)$ & $372(74.5)$ & $499(53.1)$ & 0.449 \\
\hline $\begin{array}{l}\text { There are fast queues in this clinic (e.g. } \\
\text { under 5 Immunisation, TB clients, etc) }\end{array}$ & $114(24.9)$ & $342(74.8)$ & $457(48.7)$ & 0.849 \\
\hline $\begin{array}{l}\text { The health worker that assisted me had a } \\
\text { name tag on him/her }\end{array}$ & $150(23.9)$ & $476(75.9)$ & $627(66.8)$ & 0.248 \\
\hline $\begin{array}{l}\text { I know where and to whom to raise my } \\
\text { complaints }\end{array}$ & $89(26.0)$ & $253(74.0)$ & $342(36.4)$ & 0.602 \\
\hline $\begin{array}{l}\text { When I complain I write it and put it in the } \\
\text { suggestion box provided }\end{array}$ & $85(24.7)$ & $259(75.3)$ & $344(36.6)$ & 0.606 \\
\hline When I complained I received feedback & $61(24.6)$ & $187(75.4)$ & $248(26.4)$ & 0.723 \\
\hline $\begin{array}{l}\text { Raising complaints/ suggestions improve } \\
\text { service delivery }\end{array}$ & $87(27.0)$ & $235(73.0)$ & $322(34.3)$ & 0.042 \\
\hline $\begin{array}{l}\text { I know the chairperson/member of the } \\
\text { clinic committee of this facility }\end{array}$ & $48(23.4)$ & $157(76.6)$ & $205(21.8)$ & 0.515 \\
\hline
\end{tabular}

Table 10. Service Standards. 


\subsection{Reliability}

More than three quarters of women judged services as reliable as they did not wait long before receiving medication and that the clinic provided quick services for urgent health problems. Just under this figure regarded general waiting time in waiting rooms as positive.

\begin{tabular}{|l|l|l|l|l|}
\hline Item & $\begin{array}{l}\text { Men: N } \\
\mathbf{( \% )}\end{array}$ & $\begin{array}{l}\text { Women: } \\
\text { N (\%) }\end{array}$ & $\begin{array}{l}\text { Total: N } \\
(\mathbf{\%})\end{array}$ & P \\
\hline $\begin{array}{l}\text { If I received medicines or pills I did not } \\
\text { have to wait long for them }\end{array}$ & $140(24.2)$ & $439(75.8)$ & $579(61.7)$ & 0.003 \\
\hline Waiting time in the waiting room & $106(25.2)$ & $314(74.8)$ & $420(44.7)$ & 0.062 \\
\hline $\begin{array}{l}\text { Providing quick services for urgent health } \\
\text { problems }\end{array}$ & $136(24.2)$ & $425(75.8)$ & $562(59.8)$ & 0.161 \\
\hline
\end{tabular}

Table 11. Reliability.

\subsection{Health promotion}

A majority of women respondents were positive on items referring to health promotion at the clinic. For example, more than three quarters agreed that as patients are waiting to be seen, health workers in the clinic sometimes give talks on health related issues affecting the community. Also, nearly three in four replied that when they had to wait at the clinic, very useful things can be learnt from the posters and other IEC materials. The reason for this was that the posters and other IEC materials, the 'Batho Pele' (people first) principles and the patients' rights charter, were all in a language they could understand.

\begin{tabular}{|l|l|l|l|l|}
\hline Item & $\begin{array}{l}\text { Men: N } \\
(\mathbf{\%})\end{array}$ & $\begin{array}{l}\text { Women: N } \\
(\%)\end{array}$ & $\begin{array}{l}\text { Total: N } \\
\mathbf{( \% )}\end{array}$ & P \\
\hline $\begin{array}{l}\text { I saw on the walls of this clinic a Patients } \\
\text { Rights Charter in a language I could } \\
\text { understand }\end{array}$ & $148(26.3)$ & $413(73.5)$ & $562(59.9)$ & 0.887 \\
\hline $\begin{array}{l}\text { I saw on the walls of this clinic Batho Pele } \\
\text { Principles in a language I could } \\
\text { understand }\end{array}$ & $141(26.3)$ & $395(73.6)$ & $537(57.2)$ & 0.719 \\
\hline $\begin{array}{l}\text { When I had to wait in this clinic I } \\
\text { sometimes learn very useful things from } \\
\text { the posters and other IEC (Information, } \\
\text { Education \& Communication) materials }\end{array}$ & $138(24.9)$ & $415(74.9)$ & $554(59.0)$ & 0.417 \\
\hline $\begin{array}{l}\text { The posters and other IEC material are in } \\
\text { a language I understand }\end{array}$ & $145(25.0)$ & $435(74.9)$ & $581(61.9)$ & 0.927 \\
\hline $\begin{array}{l}\text { As patients are waiting to be seen, health } \\
\text { workers in this facility sometimes talk to } \\
\text { us about health related issues that affect } \\
\text { our community }\end{array}$ & $113(22.9)$ & $379(76.9)$ & $493(52.5)$ & 0.177 \\
\hline
\end{tabular}

Table 12. Health Promotion. 


\subsection{Tangibles}

Items under the tangibles domain also yielded positive responses from the majority of women respondents. More than three in four women agreed that the toilets were clean and in a good condition, that there were indeed toilets for patients in the clinic and that the clinic has enough consultation rooms and that there were enough benches for patients to sit while waiting to be seen by health workers. Just under three quarters agreed that there was clean drinking water for patients, that the building was in a good condition and the clinic and its surroundings are clean, that the services and hours of service displayed on the board outside the clinic was clear and in a language that could be understood.

\begin{tabular}{|l|l|l|l|l|}
\hline Domain & $\begin{array}{l}\text { Men: N } \\
(\%)\end{array}$ & $\begin{array}{l}\text { Women: N } \\
(\%)\end{array}$ & $\begin{array}{l}\text { Total: N } \\
(\%)\end{array}$ & P \\
\hline The clinic building is in a good condition & $174(25.7)$ & $501(74.1)$ & $676(72.0)$ & 0.976 \\
\hline The clinic and its surroundings are clean & $182(25.5)$ & $532(74.4)$ & $715(76.1)$ & 0.903 \\
\hline There are toilets for patients in this clinic & $167(24.1)$ & $526(75.8)$ & $694(73.9)$ & 0.026 \\
\hline The toilets are in a good condition & $150(23.7)$ & $483(76.2)$ & $634(67.5)$ & 0 \\
\hline The toilets are clean & $146(23.7)$ & $468(76.1)$ & $615(65.5)$ & 0.009 \\
\hline The clinic has enough consultation rooms & $137(24.5)$ & $421(75.3)$ & $559(59.5)$ & 0.282 \\
\hline $\begin{array}{l}\text { There are benches for patients to sit while } \\
\text { waiting to be seen by health worker }\end{array}$ & $165(24.5)$ & $507(75.3)$ & $673(71.7)$ & 0.615 \\
\hline There is clean water for patients in this clinic & $171(25.1)$ & $509(74.7)$ & $681(72.5)$ & 0.432 \\
\hline $\begin{array}{l}\text { The services rendered and hours of service are } \\
\text { clearly displayed on a board outside the facility }\end{array}$ & $149(26.0)$ & $424(73.9)$ & $574(61.1)$ & 0.463 \\
\hline $\begin{array}{l}\text { The services and hours of service displayed on } \\
\text { the board outside are in a language I can } \\
\text { understand }\end{array}$ & $142(25.2)$ & $421(74.6)$ & $564(60.1)$ & 0.378 \\
\hline
\end{tabular}

Table 13. Tangibles.

\subsection{Assurance}

A greater percentage of women than men also responded positively to items of the assurance domain. More than three quarters of women agreed that the staff at the clinic had given preferential treatment to patients who looked more ill, that the nurses were able to tell them more about their illness and symptoms, and that were told how to store and selfadminister their medication. The same proportion also agreed that health workers gave them help in dealing with the emotional problems related to your health status, that they felt comfortable to bring their partners to the facility when requested and that they felt assured that their treatment records remained confidential. Exactly three quarters agreed with their physical examination by health workers, and that they helped in making their patients understand the importance of following his or her medical advice and their preparation of patients as to what to expect from specialist or hospital care.

Just under three quarters of women respondents agreed that attending the health service meant quick relief of one's symptoms, that the explanation of the purpose of tests and treatments were clear and that they felt compelled to complete their treatment as was instructed. Slightly less than three in four women agreed that health workers at the facility listened to patients, that they can get them to always return when asked to do so and that they involved their patients in decisions affecting their medical care. The same proportion of women felt that health workers also helped patients to feel well enough to perform 
normal daily activities, were through, knew what advice were given to patients previously and were competent in offering advice on the prevention of diseases.

\begin{tabular}{|l|l|l|l|l|}
\hline Domain & $\begin{array}{l}\text { Men: N } \\
(\mathbf{\%})\end{array}$ & $\begin{array}{l}\text { Women: } \\
\mathbf{N}(\%)\end{array}$ & $\begin{array}{l}\text { Total: N } \\
(\mathbf{\%})\end{array}$ & $\mathbf{P}$ \\
\hline $\begin{array}{l}\text { At the time I was waiting to be seen by a Health } \\
\text { Worker there was a patient that looked more ill }\end{array}$ & $89(23.8)$ & $285(76.2)$ & $374(39.8)$ & 0.172 \\
\hline $\begin{array}{l}\text { I always return when asked by the nurse to come } \\
\text { back }\end{array}$ & $183(25.4)$ & $536(74.4)$ & $720(76.7)$ & 0.381 \\
\hline I finish all my treatment as instructed & $190(25.3)$ & $559(74.5)$ & $750(79.9)$ & 0.885 \\
\hline I bring my partner(s) when requested to & $157(24.7)$ & $478(75.2)$ & $636(67.7)$ & 0.852 \\
\hline I was told how to take my pills/medication & $187(24.6)$ & $572(75.3)$ & $799(80.9)$ & 0.433 \\
\hline I was told how to store my pills/medication & $171(24.5)$ & $527(75.4)$ & $699(74.4)$ & 0.136 \\
\hline $\begin{array}{l}\text { Involving you in decisions about your medical } \\
\text { care }\end{array}$ & $168(25.8)$ & $483(74.2)$ & $652(69.4)$ & 0.608 \\
\hline Listening to you & $182(25.5)$ & $533(74.5)$ & $716(76.3)$ & 0.934 \\
\hline Keeping your records and data confidential & $175(24.6)$ & $529(75.1)$ & $705(75.0)$ & 0.956 \\
\hline Quick relief of your symptoms & $167(25.4)$ & $490(74.6)$ & $658(70.1$ & 0.917 \\
\hline $\begin{array}{l}\text { Helping you to feel well so that you can perform } \\
\text { your normal daily activities }\end{array}$ & $172(25.9)$ & $493(74.1)$ & $665(70.9)$ & 0.213 \\
\hline Thoroughness & $150(26.5)$ & $416(73.5)$ & $567(60.4)$ & 0.499 \\
\hline Physical examination of you & $155(25.0)$ & $466(75.0)$ & $622(66.3)$ & 0.202 \\
\hline Offering you services for preventing diseases & $168(26.2)$ & $473(73.8)$ & $642(68.4)$ & 0.228 \\
\hline Explaining the purpose of tests and treatments & $173(25.4)$ & $509(74.6)$ & $683(72.7)$ & 0.356 \\
\hline $\begin{array}{l}\text { Telling you what you wanted to know about } \\
\text { your symptoms and/or illness }\end{array}$ & $162(24.0)$ & $514(76.0)$ & $678(72.2)$ & 0.604 \\
\hline $\begin{array}{l}\text { Help in dealing with emotional problems related } \\
\text { to your health status }\end{array}$ & $161(24.7)$ & $490(75.3)$ & $651(69.3)$ & 0.237 \\
\hline $\begin{array}{l}\text { Helping you understand the importance of } \\
\text { following his or her advice }\end{array}$ & $168(25.1)$ & $502(75.0)$ & $671(71.4)$ & 0.488 \\
\hline $\begin{array}{l}\text { Knowing what s/he had done or told you during } \\
\text { previous contacts }\end{array}$ & $162(26.0)$ & $461(74.0)$ & $624(66.5)$ & 0.406 \\
\hline $\begin{array}{l}\text { Preparing you for what to expect from specialist } \\
\text { or hospital care }\end{array}$ & $155(25.1)$ & $463(75.0)$ & $619(66.0)$ & 0.914 \\
\hline
\end{tabular}

Table 14. Assurance.

\section{Discussion}

Seeking to understand patient perspectives is an important step in the efforts to improve the quality of health care. Research examining patient satisfaction with health care provision in South Africa and, more specifically, the perceived quality of care given by the health care providers is limited (Myburgh et al., 2005). In this study, there were consistently significant differences regarding patient satisfaction between male and female patients across selected items in the various domains.

Evidence from developed countries for gender differences in mean satisfaction levels is mixed. Some authors report that women are more satisfied than men with medical care received (Weiss, 1988), and some report that women are more critical of medical care than 
men \#(Kaplan, 1996), whilst a 2005 Canadian study (Human Resources and Skills Development Canada, 2009) found almost similar satsifaction levels between male (86\%) and female $(84 \%)$ patients. However, a meta-analysis of 110 studies of patient satisfaction, using standard instruments, concluded that there was no average difference in satisfaction with medical care between women and men (Hall \& Dornan, 1990). More recently, Sanmartin et al. (2002) suggested that user frequency might influence the descrepancies found betwee male and female patient statisfaction rates and that the type of service being assessed might be a further factor.

Wessels et al (2010) found that amongst oncology patients women rated care aspect of services more highly. A recent Ugandan study found some gender and age difference in patient satisfaction with TB services (Babikako et al. 2011). Past experience and consequently patient expectations, they argue might influence age and gender differences in patient satisfaction.

What is common across these studies is the importance of considering the influence of demographic variables on patient satisfaction. Simply controlling for demographic differences, might result in the needs of important demographic groupings being overlooked. In addition, demographic differences, such as gender are likely to shape patients' needs and preferences and might be a particularly important consideration in shaping specific health services to better meet needs and support treatment adherence. In the South African context, the role that gender plays in patient satisfaction and the gender differences in patient satisfaction need further exploration. We conclude that quality improvement and research in primary care could benefit from gender analysis of patient satisfaction data and from more gender-sensitive patient satisfaction measures.

\section{Acknowledgements}

We thank the Eastern Cape Department of Health for financially supporting the study. We would like to extend our gratitude to the district manager and clinic managers of the 12 clinics for overseeing the study in their respective clinics.

Our gratitude is also due to the fieldworkers and patients who agreed to be interviewed.

\section{References}

Ajayi, I.O., Olumide, E.A. \& Oyediran, O., 2005, 'Patient satisfaction with the services provided at a general outpatients' clinic, Ibadan, Oyo State, Nigeria', African Journal of Medicine \& Medical Science 34(2), 133-140.

Andaleeb, S.S., 2001, 'Service quality perceptions and patient satisfaction: a study of hospitals in a developing country', Social Science \& Medicine 52, 1359-1370.

Babikako, H.M., Neuhauser, D., Katamba, A., Mupere, E.(2011). Patient satisfaction, feasibility and reliability of satisfaction questionnaire among patients with pulmonary tuberculosis in urban Uganda: a cross-sectional study. Health Research Policy and Systems 2011, 9:6. Available from: http:/ / www.health-policy-systems.com/content/9/1/6

Bediako, M.A., Nel, M. \& Hiemstra, L.A., 2006, 'Patients' satisfaction with government health care and services in the Taung district, North West Province' Curationis 29(2), 12-15.

Bradshaw D, Groenewald P, Laubscher R, Nannan N, Nojilana B, Norman R, Pieterse D and Schneider M. Initial Burden of Disease Estimates for South Africa, 2000. Cape Town: South African Medical Research Council, 2003. 
Brislin, R.W., 1970, 'Back translation for cross-cultural research', Journal of Cross-Cultural Psychology 1(3), 185-216.

Campbell, J.L., Ramsay, J. \& Green, J., 2001, 'Age, gender, socioeconomic and ethnic differences in patients' assessments of primary health care', Quality in Health Care 10, 90-95.

Dağdeviren, N. \& Akturk, Z., 2004, 'An evaluation of patient satisfaction in Turkey with the EUROPEP instrument', Yonsei Medical Journal 45(1), 23-28.

De Jager ,J., \& Du Plooy, T., 2007, 'Service quality assurance and tangibility for public health care in South Africa' Acta Commercii 7, 96-117.

Department of Health, 2007, A policy on quality in health care for South Africa, Department of Health, Pretoria.

Department of Public Service and Administration, 1997, Transforming Public Service Delivery, Department of Public Service and Administration, Pretoria.

Eastern Cape Socio-Economic Consultative Council (ECSECC) 2011. Statistics at your fingertips $h t t p: / / w w w . e c s e c c . o r g / s t a t i s t i c s-d a t a b a s e$ [Accessed 28 June 2011]

Glick, P., 2009, 'How reliable are surveys of client satisfaction with healthcare services? Evidence from matched facility and household data in Madagascar', Social Science $\mathcal{E}$ Medicine 68(2), 368-379.

Hall, J.A. \& Dornan, M.C., 1990, ‘Patient socio-demographic characteristics as predictors of satisfaction with medical care: A meta-analysis, Social Science \& Medicine, 30(7), 811-818.

Hospital Association of South Africa, 2011. http://www.hasa.co.za/hospitals/members/ [Accessed 28 June 2011]

Kaplan SH, Sullivan LM, Spetter D. Gender and patterns of physician-patient communication. In: Falik MM, Collins KS, eds. Women's health: The Commonwealth Fund Survey. Baltimore, MD: Johns Hopkins University Press; 1996.

McIntyre D, 2010, Private sector involvement in funding and providing health services in South Africa: implications for equity and access to health care, EQUINET Discussion Paper Series 84 Health Economics Unit (UCT), ISER Rhodes University, EQUINET: Harare.

Muhondwa, E.P., Leshabari, M.T., Mwangu, M., Mbembati, N. \& Ezekiel, M.J., 2008, 'Patient satisfaction at the Muhimbili National Hospital in Dar es Salaam, Tanzania', East African Journal of Public Health 5(2), 67-73.

Myburgh, N.G., Solanki, G.C., Smith, M.J. \& Lalloo, R., 2005, ‘Patient satisfaction with health care providers in South Africa: the influences of race and socioeconomic status', International Journal for Quality in Health Care 17(6), 473-477.

Peltzer, K., 2009, 'Patient experiences and health system responsiveness in South Africa' , BMC Health Services Research 9, 117, DOI:10.1186/1472-6963-9-117.

Peltzer, K., 2000, 'Community perceptions of biomedical health care in a rural area in the Limpopo Province South Africa', Health SA Gesondheid 5 (1), 55-63.

Newman, R.D., Gloyd, S., Nyangezi, J.M., Machobo, F. \& Muiser, J., 1998, 'Satisfaction with Outpatient Health Care Services in Manica Province, Mozambique', Health Policy $\mathcal{E}$ Planning 13(2), 174-180.

Sanmartin, C., Houle, C., Berthelot, J. \& White, K., 2002, Access to Health Care Services in Canada, 2001; Statistics Canada, Ottawa.

Weiss, G.L., 1988, 'Patient Satisfaction with Primary Medical Care Evaluation of Sociodemographic and Predispositional Factors', Medical Care 26(4), 383-392.

Wessels, H., De Graff, A., Wynia, K., De Heus, M., Kruitwagen, C.L.J.J., Woltjer, G.T.G.J., Teunissen, S.C.C.M., Voest, E. (2010). Gender-Related Needs and Preferences in Cancer Care Indicate the Need for an Individualized Approach to Cancer Patients. The Oncologist,15:648-655 doi: 10.1634/theoncologist.2009-0337 


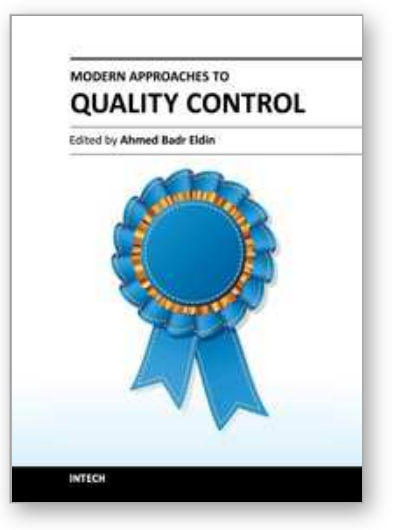

\author{
Modern Approaches To Quality Control \\ Edited by Dr. Ahmed Badr Eldin
}

ISBN 978-953-307-971-4

Hard cover, 538 pages

Publisher InTech

Published online 09, November, 2011

Published in print edition November, 2011

Rapid advance have been made in the last decade in the quality control procedures and techniques, most of the existing books try to cover specific techniques with all of their details. The aim of this book is to demonstrate quality control processes in a variety of areas, ranging from pharmaceutical and medical fields to construction engineering and data quality. A wide range of techniques and procedures have been covered.

\title{
How to reference
}

In order to correctly reference this scholarly work, feel free to copy and paste the following:

N. Phaswana-Mafuya, A. S. Davids, I. Senekal and S. Munyaka (2011). Patient Satisfaction with Primary Health Care Services in a Selected District Municipality of the Eastern Cape of South Africa, Modern Approaches To Quality Control, Dr. Ahmed Badr Eldin (Ed.), ISBN: 978-953-307-971-4, InTech, Available from: http://www.intechopen.com/books/modern-approaches-to-quality-control/patient-satisfaction-withprimary-health-care-services-in-a-selected-district-municipality-of-the-ea

\section{INTECH}

open science | open minds

\author{
InTech Europe \\ University Campus STeP Ri \\ Slavka Krautzeka 83/A \\ 51000 Rijeka, Croatia \\ Phone: +385 (51) 770447 \\ Fax: +385 (51) 686166 \\ www.intechopen.com
}

\author{
InTech China \\ Unit 405, Office Block, Hotel Equatorial Shanghai \\ No.65, Yan An Road (West), Shanghai, 200040, China \\ 中国上海市延安西路65号上海国际贵都大饭店办公楼 405 单元 \\ Phone: +86-21-62489820 \\ Fax: +86-21-62489821
}


(C) 2011 The Author(s). Licensee IntechOpen. This is an open access article distributed under the terms of the Creative Commons Attribution 3.0 License, which permits unrestricted use, distribution, and reproduction in any medium, provided the original work is properly cited. 